University of Nebraska - Lincoln

DigitalCommons@University of Nebraska - Lincoln

2-8-2001

\title{
Gap filling strategies for long term energy flux data sets
}

\author{
Eva Falge \\ University of California, Berkeley \\ Dennis D. Baldocchi \\ University of California, Berkeley, baldocchi@berkeley.edu \\ Richard Olson \\ Oak Ridge National Laboratory, Environmental Science Division \\ Peter Anthoni \\ Oregon State University, Corvallis \\ Marc Aubinet \\ Unité de Physique, Faculté des Sciences Agronomiques de Gembloux, B-50 30 Gembloux, Belgium \\ See next page for additional authors
}

Follow this and additional works at: https://digitalcommons.unl.edu/natrespapers

Part of the Natural Resources and Conservation Commons

Falge, Eva; Baldocchi, Dennis D.; Olson, Richard; Anthoni, Peter; Aubinet, Marc; Bernhofer, Christian; Burba, George; Ceulemans, Reinhart; Clement, Robert; Dolman, Han; Granier, Andre; Gross, Patrick; Grunwald, Thomas; Hollinger, David; Jensen, Niels-Otto; Katul, Gabriel; Keronen, Petri; Kowalski, Andrew; Ta Lai, Chun; Law, Beverly E.; Meyers, Tilden; Moncrieff, John; Moors, Eddy; Munger, J. William; Pilegaard, Kim; Rannik, Ullar; Rebmann, Corinna; Suyker, Andrew E.; Tenhunen, John; Tu, Kevin; Verma, Shashi; Vesala, Timo; Wilson, Kell; and Wofsy, Steve, "Gap filling strategies for long term energy flux data sets" (2001). Papers in Natural Resources. 54.

https://digitalcommons.unl.edu/natrespapers/54

This Article is brought to you for free and open access by the Natural Resources, School of at DigitalCommons@University of Nebraska - Lincoln. It has been accepted for inclusion in Papers in Natural Resources by an authorized administrator of DigitalCommons@University of Nebraska - Lincoln. 


\section{Authors}

Eva Falge, Dennis D. Baldocchi, Richard Olson, Peter Anthoni, Marc Aubinet, Christian Bernhofer, George Burba, Reinhart Ceulemans, Robert Clement, Han Dolman, Andre Granier, Patrick Gross, Thomas

Grunwald, David Hollinger, Niels-Otto Jensen, Gabriel Katul, Petri Keronen, Andrew Kowalski, Chun Ta Lai, Beverly E. Law, Tilden Meyers, John Moncrieff, Eddy Moors, J. William Munger, Kim Pilegaard, Ullar

Rannik, Corinna Rebmann, Andrew E. Suyker, John Tenhunen, Kevin Tu, Shashi Verma, Timo Vesala, Kell Wilson, and Steve Wofsy 


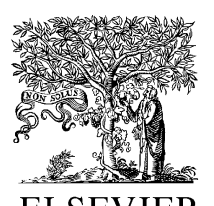

ELSEVIER

\title{
Short communication \\ Gap filling strategies for long term energy flux data sets
}

\author{
Eva Falge ${ }^{\mathrm{a}, \mathrm{r}, *}$, Dennis Baldocchi ${ }^{\mathrm{a}}$, Richard Olson ${ }^{\mathrm{b}}$, Peter Anthoni ${ }^{\mathrm{c}}$, Marc Aubinet ${ }^{\mathrm{d}}$, \\ Christian Bernhofer ${ }^{\mathrm{e}}$, George Burba ${ }^{\mathrm{f}}$, Reinhart Ceulemans ${ }^{\mathrm{g}}$, Robert Clement ${ }^{\mathrm{h}}$, \\ Han Dolman ${ }^{\mathrm{i}}$, André Granier ${ }^{\mathrm{j}}$, Patrick Gross ${ }^{\mathrm{j}}$, Thomas Grünwald ${ }^{\mathrm{e}}$, David Hollinger ${ }^{\mathrm{k}}$, \\ Niels-Otto Jensen ${ }^{1}$, Gabriel Katul ${ }^{\mathrm{m}}$, Petri Keronen ${ }^{\mathrm{n}}$, Andrew Kowalski ${ }^{\mathrm{g}}$, \\ Chun Ta Lai $^{\mathrm{m}}$, Beverley E. Law ${ }^{\mathrm{c}}$, Tilden Meyers ${ }^{\mathrm{o}}$, John Moncrieff ${ }^{\mathrm{h}}$, Eddy Moors ${ }^{\mathrm{i}}$, \\ J. William Munger ${ }^{p}$, Kim Pilegaard ${ }^{\mathrm{l}}$, Üllar Rannik ${ }^{\mathrm{n}}$, Corinna Rebmann ${ }^{\mathrm{q}}$, \\ Andrew Suyker ${ }^{\mathrm{f}}$, John Tenhunen ${ }^{\mathrm{r}}$, Kevin Tu ${ }^{\mathrm{s}}$, Shashi Verma ${ }^{\mathrm{f}}$, Timo Vesala ${ }^{\mathrm{n}}$, \\ Kell Wilson ${ }^{\mathrm{o}}$, Steve Wofsy ${ }^{\mathrm{p}}$ \\ ${ }^{a}$ ESPM, University of California, Berkeley, CA 94704, USA \\ b Oak Ridge National Laboratory, Environmental Science Division, Oak Ridge, TN, USA \\ ${ }^{\mathrm{c}}$ Richardson Hall, Oregon State University, Corvallis, OR 97331-2209, USA \\ ${ }^{\mathrm{d}}$ Unité de Physique, Faculté des Sciences Agronomiques de Gembloux, B-50 30 Gembloux, Belgium \\ e Technische Universität Dresden, IHM Meteorologie, Pienner Str. 9, 01737 Tharandt, Germany \\ ${ }^{\mathrm{f}}$ School of Natural Resource Sciences, 244 L.W. Chase Hall, P.O. Box 830728, University of Nebraska-Lincoln, Lincoln, NE 68583-0728, USA \\ ${ }^{\mathrm{g}}$ Laboratory of Plant Ecology, Department of Biology, University of Antwerpen, Universiteitsplein 1, B-2610 Wilrijk, Antwerp, Belgium \\ ${ }^{\mathrm{h}}$ Institute of Ecology and Resource Management, University of Edinburgh, Edinburgh EH9 3JU, UK \\ ${ }^{\mathrm{i}}$ Alterra, Postbus 47, 6700 AA Wageningen, The Netherlands \\ j INRA, Unité d'Ecophysiologie Forestière, F-54280 Champenoux, France \\ ${ }^{\mathrm{k}}$ USDA Forest Service, 271 Mast Rd, Durham, NH 03824, USA \\ ${ }^{1}$ Risoe National Laboratory, Plant Biology and Biogeochemistry Department, P.O. Box 49, DK-4000 Roskilde, Denmark \\ ${ }^{m}$ School of the Environment, Box 90328, Duke University, Durham, NC 27708-0328, USA \\ ${ }^{\mathrm{n}}$ Department of Physics, P.O. Box 9, University of Helsinki, FIN-00014 Helsinki, Finland \\ ${ }^{\circ}$ NOAA/ATDD, 456 S. Illinois Avenue, Oak Ridge, TN 37831-2456, USA \\ ${ }^{\mathrm{p}}$ Department of Earth and Planetary Sciences, Harvard University, 20 Oxford St., Cambridge, MA 02138, USA \\ ${ }^{\mathrm{q}}$ Max-Planck-Institut für Biogeochemie, Tatzendpromenade 1a, 07701 Jena, Germany \\ ${ }^{\mathrm{r}}$ Pflanzenökologie, Universität Bayreuth, 95440 Bayreuth, Germany \\ ${ }^{s}$ Department of Natural Resources, University of New Hampshire, Durham, NH 03824, USA
}

Received 17 August 2000; received in revised form 13 November 2000; accepted 17 November 2000

\footnotetext{
${ }^{27}$ Data provided by EUROFLUX: Corinna Rebmann/E.-D. Schulze/John Tenhunen; Thomas Grünwald/Christian Bernhofer; E.J. Moors/Jan A. Elbers/Han Dolman; Kim Pilegaard/Niels-Otto Jensen; Marc Aubinet; Üllar Rannik/Timo Vesala; André Granier/Patrick Gross; Robert Clement/John Moncrieff; Andrew Kowalski/Reinhart Ceulemans. AmeriFlux: Dennis Baldocchi/Kell Wilson; David Hollinger; Bill Munger/Steve Wofsy; Tilden Meyers; Shashi Verma/Andrew Suyker/George Burba; Peter Anthoni/Beverly Law; Chun Ta Lai/Gabriel Katul/Ram Oren.

${ }^{*}$ Corresponding author. Tel.: +49-921-55-2576; fax: +49-921-55-2564.

E-mail address: falge@uni-bayreuth.de (E. Falge).
}

0168-1923/01/\$ - see front matter @ 2001 Elsevier Science B.V. All rights reserved.

PII: S 0 168-1923(00)00235-5 


\begin{abstract}
At present a network of over 100 field sites are measuring carbon dioxide, water vapor and sensible heat fluxes between the biosphere and atmosphere, on a nearly continuous basis. Gaps in the long term measurements of evaporation and sensible heat flux must be filled before these data can be used for hydrological and meteorological applications. We adapted methods of gap filling for NEE (net ecosystem exchange of carbon) to energy fluxes and applied them to data sets available from the EUROFLUX and AmeriFlux eddy covariance databases. The average data coverage for the sites selected was $69 \%$ and $75 \%$ for latent heat $(\lambda E)$ and sensible heat $(H)$. The methods were based on mean diurnal variations (half-hourly binned means of fluxes based on previous and subsequent days, MDV) and look-up tables for fluxes during assorted meteorological conditions (LookUp), and the impact of different gap filling methods on the annual sum of $\lambda E$ and $H$ is investigated. The difference between annual $\lambda E$ filled by MDV and $\lambda E$ filled by LookUp ranged from -120 to $210 \mathrm{MJ} \mathrm{m}^{-2}$ per year, i.e. -48 to $+86 \mathrm{~mm}$ per year, or -13 to $+39 \%$ of the annual sum. For annual sums of $H$ differences between -140 and $+140 \mathrm{MJ} \mathrm{m}^{-2}$ per year or -12 to $+19 \%$ of the annual sum were found. (C) 2001 Elsevier Science B.V. All rights reserved.
\end{abstract}

Keywords: FLUXNET; EUROFLUX; AmeriFlux; Eddy covariance; Latent heat; Sensible heat; Data filling; Interpolation techniques

\section{Introduction}

In 1997 FLUXNET, a global network of long term mass and energy $\left(\mathrm{CO}_{2}\right.$, water vapor, sensible heat) flux density measurement stations was established (Baldocchi et al., 1996, Running et al., 1999). Over 100 sites are in operation over a diverse set of landscapes, crops, grassland, conifer, deciduous and evergreen broadleaved forests. Data from the network has the potential to address problems relating to ecosystem carbon balance (Falge et al., 2000) and the water and heat balance of sites. In practice it is impossible to accept data, uncritically, $24 \mathrm{~h}$ a day, 365 days a year. Violations in micrometeorological assumptions, instrument malfunction and poor weather will force investigators to reject a proportion of the data. Yet, our interest and goals involve construction of continuous records of half-hourly fluxes measured by eddy covariance and computation of seasonal and annual sums of carbon dioxide, water and heat exchange.

Numerous filling methods for NEE have been used by others (e.g. Greco and Baldocchi, 1996, Goulden et al., 1996, Grünwald and Bernhofer, 2000, Aubinet et al., 2000, Falge et al., 2000). Studies on effects of filling methods for energy fluxes on calculated annual sums have not been reported. Long term records of energy fluxes usually are constructed on coarser time scales (months) applying for instance the water balance equation for $\lambda E$ and estimating $H$ as a residual of the energy balance equation (e.g., Jaeger and Kessler, 1997). For the filling of half-hourly energy fluxes however, methods based on the water balance equation are not applicable.

In Falge et al. (2000), filling methods of NEE were compared on the basis of flux measurements for nine EUROFLUX sites and 10 AmeriFlux sites for a total of 28 unique site-year combinations between 1992 and 1999 (see Table 1). Their results emphasized the need to standardize gap filling methods for improving the comparability of annual NEE from regional and global flux networks. The purpose of this paper is to investigate whether non-standardized filling methodologies have a similar effect on annual sums of energy fluxes and whether gap filling methods can be applied universally for crops, grasslands and conifer and broad-leaved forests. We established methods based on the concepts of mean diurnal variations and look-up tables reported in Falge et al. (2000) for filling of half-hourly values of $\lambda E$ and $H$ (both in $\mathrm{W} \mathrm{m}^{-2}$ ), and applied them to the above data sets to evaluate the need for standardized techniques.

\section{Methods}

Gap filling methods applied here include mean diurnal variations of previous periods (MDV), and look-up tables (LookUp) as defined in Falge et al. (2000). The gap filling methods were tested on the data from the 18 flux sites, summarized in Table 1. For four sites (HY97, HV96, BV97, and SH97), chosen to represent four major vegetation groups, conifers, deciduous 
Table 1

Site information for 18 sites from the EUROFLUX and AmeriFlux projects and several years (adapted from Falge et al. (2000, their Table 1))

\begin{tabular}{|c|c|c|c|c|}
\hline Site & State/country & Period & Abbreviation & Species \\
\hline \multicolumn{5}{|l|}{ Coniferous forests } \\
\hline WeidenBrunnen ${ }^{\mathrm{a}}$ & Germany & 1997 & WE97 & Norway Spruce \\
\hline Tharandt $^{\mathrm{a}}$ & Germany & 1997 & TH97 & Norway Spruce \\
\hline Loobos $^{\mathrm{a}}$ & Netherlands & 1997 & LO97 & Scots Pine \\
\hline Hyytiala $^{\mathrm{a}}$ & Finland & 1997 & HY97 & Scots Pine \\
\hline Brasschaat $^{\mathrm{a}}$ & Belgium & 1997 & BR97 & Scots Pine, Oaks \\
\hline Aberfeldy ${ }^{\mathrm{a}}$ & United Kingdom & 1997 & AB97 & Sitka Spruce \\
\hline Howland $^{\mathrm{b}}$ & Maine/USA & 1996 & HL96 & Spruce-Hemlock \\
\hline Metolius $^{\mathrm{b}}$ & Oregon/USA & 1996, 1997 & ME96, ME97 & Ponderosa Pine \\
\hline Duke forest ${ }^{b}$ & North Carolina/USA & 1998,1999 & DU98, DU99 & Loblolly Pine \\
\hline \multicolumn{5}{|l|}{ Deciduous forests } \\
\hline Vielsalm ${ }^{\mathrm{a}}$ & Belgium & 1997 & VI97 & European Beech \\
\hline Soroe $^{\mathrm{a}}$ & Denmark & 1997 & SO97 & European Beech \\
\hline Hesse $^{\mathrm{a}}$ & France & 1997 & HE97 & European Beech \\
\hline WalkerBranch $^{\mathrm{b}}$ & Tennessee/USA & 1995, 1996, 1997 & WB95, WB96, WB97 & Oak-Hickory \\
\hline Harvard $^{b}$ & Massachusetts/USA & 1992, 1993, 1994, 1995, 1996 & HV92, HV93, HV94, HV95, HV96 & Oak-Maple \\
\hline \multicolumn{5}{|l|}{ Grasslands } \\
\hline LittleWashita $^{\mathrm{b}}$ & Oklahoma/USA & 1997, 1998 & LW97, LW98 & Rangeland \\
\hline Shidler $^{\mathrm{b}}$ & Oklahoma/USA & $15 / 9 / 96-14 / 9 / 97$ & SH97 & Tallgrass Prairie \\
\hline \multicolumn{5}{|l|}{ Crops } \\
\hline Bondville $^{\mathrm{b}}$ & Illinois/USA & 1997 & BV97 & Corn \\
\hline Bondville $^{b}$ & Illinois/USA & 1998 & BV98 & Soybean \\
\hline Ponca $^{\mathrm{b}}$ & Oklahoma/USA & 21/8/96-20/8/97 & PO97 & Wheat \\
\hline
\end{tabular}

${ }^{\mathrm{a}}$ EUROFLUX

b AmeriFlux.

forests, crops, and grassland, data sets with artificially generated gaps (containing 25, 35, 45, 55, and $65 \%$ of gaps) were used to assess the accuracy of the gap filling methods. After introducing artificial gaps the respective gap filling methods were parameterised with the remaining data, and applied to fill the artificial gaps in the data sets. The absolute error for each method was calculated as the measured minus the computed value for each of the artificial gaps. The relationship between those errors summed for different time periods and the overall gap percentage in the artificial data sets were used to tabulate maximum absolute errors per percent gaps during a period (day, week, month, year), and for both filling methods (Table 2). The percentage of gaps filled during daytime and night time for a given time period was used to scale the tabulated values to an error assessment for the period. Details on these methods are given in Falge et al. (2000). In the following we report only adaptations to the methods for the filling of the gaps in the energy fluxes.
Filling by mean diurnal variations replaces missing observations by the mean for that time period (half-hourly averages) based on previous and subsequent days. For energy fluxes independent windows of 14-day-size were found to reduce errors introduced by averaging values showing nonlinear dependence on environmental variables.

The use of the mean diurnal variation to fill gaps takes no account of day to day variations in weather conditions, unlike the use of look-up table methods. For the look-up table method tables were created for each site so that missing values of $\lambda E$, and $H$ could be "looked-up" based on the environmental conditions associated with the missing data. Assigned periods were bi-monthly or seasonal, from 1 April to 31 May, 1 June to 30 September, 1 October to 30 November, and 1 December to 31 March. For $\lambda E$ and $H$ look-up tables the sorting variables were $Q_{\mathrm{p}}$ (photosynthetic photon flux density) and $D$ (vapor pressure deficit), considering $D$ as a major driver of 
Table 2

Maximum absolute errors (in $\mathrm{kJ}$ per $\mathrm{m}^{2}$ and gap percentage of period) observed for the four selected sites during the artificial gap filling experiment, for two selected filling methods (MDV: mean diurnal variation, and LookUp: look-up tables, as defined in text) and for daytime and night-time, and ecosystem latent heat $(\lambda E)$ and sensible heat $(H)$ sum separately ${ }^{\mathrm{a}}$

\begin{tabular}{|c|c|c|c|c|c|c|c|c|c|}
\hline \multirow[t]{2}{*}{ Period } & \multirow[t]{2}{*}{ Method } & \multicolumn{4}{|c|}{$\begin{array}{l}\text { Daytime: absolute }( \pm) \text { error }\left(\mathrm{kJ} \mathrm{m}^{-2}\right. \\
\text { per gap percentage of period) }\end{array}$} & \multicolumn{4}{|c|}{$\begin{array}{l}\text { Night time: absolute }( \pm) \text { error }\left(\mathrm{kJ} \mathrm{m}^{-2} \text { per }\right. \\
\text { gap percentage of period) }\end{array}$} \\
\hline & & Coniferous & Deciduous & Crops & Grasslands & Coniferous & Deciduous & Crops & Grasslands \\
\hline \multicolumn{10}{|c|}{ Latent heat $(\lambda E)$} \\
\hline \multirow[t]{2}{*}{1 day } & MDV & 35 & 30 & 25 & 25 & 10 & 25 & 25 & 20 \\
\hline & LookUp & 20 & 30 & 25 & 25 & 10 & 20 & 25 & 20 \\
\hline \multirow[t]{2}{*}{7 days } & MDV & 140 & 135 & 80 & 80 & 25 & 35 & 70 & 60 \\
\hline & LookUp & 105 & 55 & 50 & 125 & 25 & 20 & 70 & 40 \\
\hline \multirow[t]{2}{*}{30 days } & MDV & 85 & 480 & 110 & 125 & 30 & 90 & 70 & 125 \\
\hline & LookUp & 75 & 180 & 95 & 160 & 25 & 40 & 55 & 125 \\
\hline \multirow[t]{2}{*}{365 days } & MDV & 220 & 565 & 460 & 210 & 40 & 215 & 70 & 220 \\
\hline & LookUp & 150 & 380 & 285 & 215 & 45 & 155 & 65 & 240 \\
\hline \multicolumn{10}{|c|}{ Sensible heat $(H)$} \\
\hline \multirow[t]{2}{*}{1 day } & MDV & 30 & 30 & 25 & 25 & 25 & 25 & 25 & 20 \\
\hline & LookUp & 30 & 30 & 25 & 20 & 20 & 20 & 25 & 20 \\
\hline \multirow[t]{2}{*}{7 days } & MDV & 60 & 60 & 60 & 55 & 50 & 50 & 70 & 65 \\
\hline & LookUp & 75 & 75 & 60 & 55 & 50 & 50 & 70 & 65 \\
\hline \multirow[t]{2}{*}{30 days } & MDV & 105 & 105 & 95 & 190 & 75 & 75 & 130 & 315 \\
\hline & LookUp & 110 & 110 & 105 & 235 & 125 & 125 & 85 & 200 \\
\hline \multirow[t]{2}{*}{365 days } & MDV & 260 & 260 & 150 & 355 & 300 & 300 & 280 & 190 \\
\hline & LookUp & 200 & 200 & 230 & 175 & 230 & 230 & 140 & 195 \\
\hline
\end{tabular}

${ }^{a}$ To obtain an absolute error for a certain period, the values for both, daytime and night time, have to be multiplied with the respective gap percentage (e.g. 50 if half of the daytime data are missing), and the results be added. For instance, for $31 \%$ missing values during day and $25 \%$ during night, the LookUp method for "Deciduous Forest" (HV96) would result in a maximum error of $\pm 22.89 \mathrm{MJ}^{-2}$ per year $(=565 \times 31+215 \times 25)$.

$\lambda E$. For filling $\lambda E$ and $H$ missing values, average fluxes were compiled for a maximum of 6 (or 4) seasonal periods $\times 23 Q_{\mathrm{p}}$-classes $\times 35 \mathrm{D}$-classes. The $Q_{\mathrm{p}}$ classes consisted of $0.1 \mathrm{mmol} \mathrm{m}^{-2} \mathrm{~s}^{-1}$ intervals from 0 to $2.2 \mathrm{mmol} \mathrm{m}^{-2} \mathrm{~s}^{-1}$ with a separate class for $Q_{\mathrm{p}}=0$. Similarly, $D$-classes were defined through $0.15 \mathrm{kPa}$ intervals ranging from 0 to $5.1 \mathrm{kPa}$. Gaps in the look-up tables (classes with no mean assigned) were interpolated linearly, the maximum gap width spanned was $0.3 \mathrm{mmol} \mathrm{m}^{-2} \mathrm{~s}^{-1}$ for a light curve at a given $D$, and $0.45 \mathrm{kPa}$ within a $D$ curve at given light level. The method requires complete sets of $Q_{\mathrm{p}}$ and $D$, thus gaps in $Q_{\mathrm{p}}$ and $D$ were filled using MDV methods described in Falge et al. (2000).

\section{Results}

The 28 data sets had an average of $31 \%$ missing or rejected values of $\lambda E$ data and $25 \%$ for $H$ with a slightly higher percentage for night observations (Table 3). Values that are commonly observed in eddy correlation data sets (Falge et al., 2000), yet making it necessary to estimate values for a continuous data record. The large differences in the computed gap frequencies depend on different approaches of data rejection. Some sites reported all data where the instruments were working and leave data rejection to be done later, others applied sophisticated quality assurance routines (Foken and Wichura, 1995, Mahrt, 1998).

For the computation of daily, monthly and annual sums of $\lambda E$ and $H$ we filled the data sets with the above methods, and computed errors for the filled data points. The errors assigned were calculated from tabulated values of maximum errors (see Table 2) derived from the results of a sensitivity analysis of various methods for each functional group, i.e. conifers, deciduous forests, crops, and grassland (see Section 2), 
Table 3

Percentages of latent $(\lambda E)$ and sensible $(H)$ heat flux data, that were missing or had to be rejected for 18 sites from the EUROFLUX and AmeriFlux projects and several years ${ }^{\mathrm{a}}$

\begin{tabular}{|c|c|c|c|c|c|c|}
\hline \multirow[t]{2}{*}{ Site } & \multicolumn{3}{|c|}{$\lambda E$ gap percentage } & \multicolumn{3}{|c|}{$H$ gap percentage } \\
\hline & Day & Total & Night & Day & Total & Night \\
\hline \multicolumn{7}{|c|}{ Coniferous forests } \\
\hline WE97 & 63.1 & 69.0 & 75.0 & 28.1 & 30.4 & 32.6 \\
\hline TH97 & 29.7 & 35.0 & 40.5 & 25.3 & 32.7 & 40.3 \\
\hline LO97 & 10.8 & 11.5 & 12.1 & 8.3 & 8.6 & 8.9 \\
\hline HY97 & 23.3 & 23.2 & 23.1 & 18.3 & 18.9 & 19.5 \\
\hline BR97 & 37.3 & 34.2 & 31.1 & 37.6 & 34.4 & 31.3 \\
\hline AB97 & 23.5 & 24.0 & 24.5 & 20.5 & 20.6 & 20.7 \\
\hline HL96 & 42.5 & 40.9 & 39.2 & 30.9 & 28.5 & 26.0 \\
\hline ME96 & 39.0 & 44.3 & 49.7 & 39.0 & 44.3 & 49.5 \\
\hline ME97 & 48.6 & 52.5 & 56.4 & 48.6 & 52.5 & 56.4 \\
\hline DU98 & 59.8 & 59.5 & 59.2 & 50.1 & 51.0 & 52.0 \\
\hline DU99 & 38.9 & 39.9 & 40.9 & 36.0 & 36.3 & 36.6 \\
\hline \multicolumn{7}{|c|}{ Deciduous forests } \\
\hline VI97 & 11.1 & 10.4 & 9.7 & - & - & - \\
\hline SO97 & 4.7 & 4.7 & 4.6 & 5.1 & 5.4 & 5.6 \\
\hline HE97 & 4.6 & 4.2 & 3.7 & 6.2 & 6.3 & 6.5 \\
\hline WB95 & 26.5 & 30.5 & 34.6 & 27.5 & 34.3 & 41.0 \\
\hline WB96 & 23.8 & 27.4 & 31.0 & 24.2 & 29.7 & 35.2 \\
\hline WB97 & 26.5 & 30.1 & 33.8 & 27.0 & 33.1 & 39.2 \\
\hline HV92 & 36.5 & 34.4 & 32.3 & 30.3 & 28.0 & 25.7 \\
\hline HV93 & 57.0 & 56.5 & 55.9 & 46.5 & 45.6 & 44.6 \\
\hline HV94 & 26.6 & 24.7 & 22.7 & 18.2 & 16.0 & 13.8 \\
\hline HV95 & 25.8 & 25.7 & 25.6 & 21.2 & 21.8 & 22.4 \\
\hline HV96 & 47.8 & 43.4 & 39.0 & 14.9 & 14.3 & 13.7 \\
\hline \multicolumn{7}{|l|}{ Grasslands } \\
\hline LW97 & 9.6 & 11.1 & 12.5 & 5.4 & 6.6 & 7.7 \\
\hline LW98 & 15.7 & 16.9 & 18.1 & 11.1 & 11.5 & 11.9 \\
\hline SH97 & 26.4 & 27.2 & 28.1 & 21.4 & 22.5 & 23.7 \\
\hline \multicolumn{7}{|l|}{ Crops } \\
\hline BV97 & 14.0 & 17.4 & 21.0 & 11.4 & 14.6 & 17.8 \\
\hline BV98 & 17.3 & 20.6 & 23.9 & 7.8 & 10.2 & 12.7 \\
\hline PO97 & 41.3 & 41.7 & 42.2 & 30.8 & 29.2 & 27.5 \\
\hline Average & 29.7 & 30.7 & 31.8 & 24.1 & 25.4 & 26.8 \\
\hline S.D. & 16.3 & 16.5 & 17.1 & 13.2 & 13.7 & 14.7 \\
\hline
\end{tabular}

${ }^{a}$ For site abbreviations, see Table 1.

and the percentage of gaps during daytime and night time.

Comparing the annual sums of data filled by mean diurnal variation methods with look-up table methods (Table 4), the effect for evapotranspiration data ranged between -121 and $205 \mathrm{MJ} \mathrm{m}^{-2}$ per year with an average of $+25 \mathrm{MJ} \mathrm{m}^{-2}$ per year, i.e. -48 to $86 \mathrm{~mm}$ per year with an average of $+10 \mathrm{~mm}$ per year. The effect for filling sensible heat with different methods ranged between -137 and $+138 \mathrm{MJ} \mathrm{m}^{-2}$ per year, with an average of $+34 \mathrm{MJ} \mathrm{m}^{-2}$ per year. On average and in percent of the annual sums, these effects are small: $+2.7 \%$ for $\lambda E$, and $+4.5 \%$ for $H$. However, for single sites they could be as large as -12.9 or $+39.4 \%$ of $\lambda E$, and -12.2 or $+19.4 \%$ of $H$. Since these differences are purely due to the use of alternative methods of gap filling they could be avoided by applying a common gap filling protocol.

The annual sums of energy fluxes resulting from the selected methods are not necessarily compatible with each other. A linear regression between $\lambda E_{\mathrm{LookUp}}$ and $\lambda E_{\mathrm{MDV}}$ results in $a=+1.615 \mathrm{MJ} \mathrm{m}^{-2}$ per year, $b=0.976, r^{2}=0.97$, indicating an overestimation by MDV compared to look-up tables ( $a$ being close to zero). Similarly, MDV filled data of $H$ overestimate $H$ filled by look-up tables, with linear regression coefficients between $H_{\text {LookUp }}$ and $H_{\mathrm{MDV}}$ of $a=+6.051 \mathrm{MJ} \mathrm{m}^{-2}$ per year, $b=0.952, r^{2}=$ 0.96 .

\section{Discussion}

The filling methodologies (mean diurnal variations, look-up tables) we discussed in this paper showed good approximation to the original data and small errors. On average, annual sums filled by these methods differed by only $10 \mathrm{~mm}$ per year for $\lambda E$, and $34 \mathrm{MJ} \mathrm{m}^{-2}$ per year for $H$. However, we were unable to answer which method compared best with the artificially removed data. The residuals between artificially removed and filled data could not be distinguished by ANOVA, due to the overall scatter of eddy covariance data that built the basis for the artificial data removing.

For filling of sensible and latent heat fluxes we did not apply a (nonlinear) regression model, but used MDV and LookUp methods only. Possible functions for filling $\lambda E$, or $H$ from measurements of insolation, vapor pressure deficit, or temperature would be the energy balance equation, or the Penman-Monteith equation, where the basic concept is also energy balance closure (Monteith, 1965), but would need information on canopy air, boundary, and stomatal conductances in addition. Especially for the data in hand, we avoided applying concepts based on 
Table 4

Energy equivalent of ecosystem evapotranspiration $(\lambda E)$ and sensible heat flux sum $(H)$, and respective errors introduced during the gap filling ${ }^{\mathrm{a}}$

\begin{tabular}{|c|c|c|c|c|c|c|c|c|c|c|}
\hline \multirow[t]{2}{*}{ Site } & \multicolumn{4}{|c|}{$\lambda E\left(\mathrm{MJ} \mathrm{m}^{-2}\right.$ per year $)$} & \multirow{2}{*}{$\frac{\lambda E}{\text { Rel. Diff. (\%) }}$} & \multicolumn{4}{|c|}{$H\left(\mathrm{MJ} \mathrm{m}^{-2}\right.$ per year $)$} & \multirow{2}{*}{$\begin{array}{l}H \\
\text { Rel. Diff. (\%) }\end{array}$} \\
\hline & MDV & Error & LookUp & Error & & MDV & Error & LookUp & Error & \\
\hline \multicolumn{11}{|c|}{ Coniferous forests } \\
\hline WE97 & 726 & 17 & 521 & 13 & 39 & - & - & - & - & - \\
\hline TH97 & 1177 & 8 & 1205 & 6 & -2 & 624 & 19 & 621 & 14 & 1 \\
\hline LO97 & 1045 & 3 & 1027 & 2 & 2 & 358 & 5 & 325 & 4 & 10 \\
\hline HY97 & 786 & 6 & 777 & 5 & 1 & 425 & 11 & 443 & 8 & -4 \\
\hline BR97 & 495 & 9 & 568 & 7 & -13 & 320 & 19 & 336 & 15 & -5 \\
\hline AB97 & 519 & 6 & 514 & 5 & 1 & 330 & 12 & 278 & 9 & 19 \\
\hline HL96 & 974 & 11 & 878 & 8 & 11 & 1020 & 16 & 918 & 12 & 11 \\
\hline ME96 & 1307 & 11 & 1236 & 8 & 6 & 986 & 25 & 1123 & 19 & -12 \\
\hline ME97 & 1041 & 13 & 944 & 10 & 10 & 1207 & 30 & 1138 & 23 & 6 \\
\hline DU98 & 1117 & 16 & 1238 & 12 & -10 & 842 & 29 & 807 & 22 & 4 \\
\hline DU99 & 1414 & 10 & 1351 & 8 & 5 & 1153 & 20 & 1043 & 16 & 11 \\
\hline \multicolumn{11}{|c|}{ Deciduous forests } \\
\hline VI97 & 642 & 8 & 642 & 5 & 0 & - & - & - & - & - \\
\hline SO97 & 641 & 4 & 639 & 2 & 0 & 766 & 3 & 751 & 2 & 2 \\
\hline HE97 & 853 & 3 & 852 & 2 & 0 & 371 & 4 & 394 & 3 & -6 \\
\hline WB95 & 1370 & 22 & 1350 & 15 & 1 & 1015 & 19 & 954 & 15 & 6 \\
\hline WB96 & 1436 & 20 & 1372 & 14 & 5 & 969 & 17 & 875 & 13 & 11 \\
\hline WB97 & 1566 & 22 & 1501 & 15 & 4 & 1099 & 19 & 1018 & 14 & 8 \\
\hline HV92 & 953 & 28 & 937 & 19 & 2 & 1117 & 16 & 1061 & 12 & 5 \\
\hline HV93 & 1464 & 44 & 1390 & 30 & 5 & 851 & 25 & 713 & 20 & 19 \\
\hline HV94 & 1430 & 20 & 1410 & 14 & 1 & 986 & 9 & 998 & 7 & -1 \\
\hline HV95 & 1292 & 20 & 1293 & 14 & 0 & 1114 & 12 & 1098 & 9 & 1 \\
\hline HV96 & 882 & 35 & 948 & 24 & -7 & 1024 & 8 & 983 & 6 & 4 \\
\hline \multicolumn{11}{|c|}{ Grasslands } \\
\hline LW97 & 1203 & 5 & 1164 & 5 & 3 & 1251 & 3 & 1243 & 2 & 1 \\
\hline LW98 & 974 & 7 & 980 & 8 & -1 & 1346 & 6 & 1332 & 4 & 1 \\
\hline SH97 & 1613 & 12 & 1484 & 12 & 9 & 745 & 12 & 705 & 8 & 6 \\
\hline \multicolumn{11}{|l|}{ Crops } \\
\hline BV97 & 1352 & 8 & 1321 & 5 & 2 & 892 & 7 & 880 & 3 & 1 \\
\hline BV98 & 1632 & 10 & 1588 & 6 & 3 & 653 & 5 & 646 & 2 & 1 \\
\hline PO97 & 2038 & 22 & 2099 & 15 & -3 & 925 & 12 & 801 & 8 & 16 \\
\hline
\end{tabular}

${ }^{a}$ Filling for $\lambda E$ and $H$ involved mean diurnal variations (MDV), and look-up tables (LookUp), as described in the text. The errors were calculated by multiplying the gap percentage for a certain period (daytime and night time separately) with tabulated values of maximum errors observed during an experiment to fill artificial gaps (for details see text). Relative differences (Rel. Diff.) between annual sums derived by the two methods are calculated as $\left(\left(\lambda E_{\mathrm{MDV}}-\lambda E_{\mathrm{LookUp}}\right) / \lambda E_{\mathrm{LookUp}}\right) \times 100 \%$, and $\left(\left(H_{\mathrm{MDV}}-H_{\mathrm{LookUp}}\right) / H_{\mathrm{LookUp}}\right) \times 100 \%$, respectively. For site abbreviations see Table 1.

energy balance closure, since the sum of the eddy covariance fluxes was on average $13 \%$ less than the available energy, i.e. sum of the radiation, soil heat fluxes and the change in the storage terms. Energy flux underestimation seems to occur frequently when using eddy covariance measurements (Twine et al., 2000).
Errors of gap-filling can have two sources, the error introduced by different research groups applying different filling methodologies, and the error introduced during the filling process. The errors during the filling process differed slightly between methods, those introduced by MDV being on average $3.9 \mathrm{MJ} \mathrm{m}^{-2}$ per year for $\lambda E$, and $3.5 \mathrm{MJ} \mathrm{m}^{-2}$ per 
year for $H$ higher than those for LookUp. Maximum observed differences in errors are $13.9 \mathrm{MJ} \mathrm{m}^{-2}$ per year for $\lambda E$, and $6.9 \mathrm{MJ} \mathrm{m}^{-2}$ per year for $H$. If fillings were performed with differing methods, the (maximum) differences in annual sums (i.e. -121 to $+205 \mathrm{MJ} \mathrm{m}^{-2}$ per year for $\lambda E$, and -137 to $+138 \mathrm{MJ} \mathrm{m}^{-2}$ per year for $H$ ) would add to the error above.

\section{Conclusion}

The results reported here emphasize the importance of a method of standardization during the data post-processing phase, as annual sums of energy fluxes resulting from the selected methods are not necessarily compatible with each other. Annual sums resulting from filling by look-up tables are in general slightly smaller than data filled by mean diurnal variation.

For comparison with output of soil vegetation atmosphere transfer (SVAT) models driven by meteorological conditions, we would propose semi-empirical methods because they preserve the response of energy fluxes to main meteorological conditions (e.g. $Q_{\mathrm{p}}, D$ ). Thus, look-up table methods should be preferred for standardized filling protocols for ecosystem fluxes, to provide for consistent data bases for synthesis issues in progress.

\section{Acknowledgements}

This work is supported by NASA's EOS Validation Project and contributes to the EUROFLUX, AmeriFlux, and FLUXNET programs. We also acknowledge and appreciate funding for the numerous sites by the European Union (EUROFLUX project), US Department of Energy's Terrestrial Carbon Program, and NIGEC Program (AmeriFlux projects).

\section{References}

Aubinet, M., Grelle, A., Ibrom, A., Rannik, Ü., Moncrieff, J., Foken, T., Kowalski, A.S., Martin, P.H., Berbigier, P., Bernhofer, Ch., Clement, R., Elbers, J., Granier, A., Grünwald, T., Morgenstern, K., Pilegaard, K., Rebmann, C., Snijders, W., Valentini, R., Vesala, T., 2000. Estimates of the annual net carbon and water exchange of forests: the EUROFLUX methodology. Adv. Ecol. Res. 30, 113-175.

Baldocchi, D.D., Valentini, R., Running, S.R., Oechel, W., Dahlman, R., 1996. Strategies for measuring and modelling carbon dioxide and water fluxes over terrestrial ecosystems. Global Change Biol. 2, 159-168.

Falge, E., Baldocchi, D., Olson, R., et al., 2001. Gap filling strategies for defensible annual sums of net ecosystem exchange. Agric. For. Meteorol. 107, 43-69.

Foken, Th., Wichura, B., 1995. Tools for quality assessment of surface-based flux measurements. Agric. For. Meteorol. 78, 83105.

Goulden, M.L., Munger, J.W., Fan, S.M., Daube, B.C., Wofsy, S.C., 1996. Measurement of carbon storage by long-term eddy correlation: methods and a critical assessment of accuracy. Global Change Biol. 2, 169-182.

Greco, S., Baldocchi, D.D., 1996. Seasonal variations of $\mathrm{CO}_{2}$ and water vapour exchange rates over a temperate deciduous forest. Global Change Biol. 2, 183-198.

Grünwald, Th., Bernhofer, Ch., 2000. Regression modelling used for data gap filling of carbon flux measurements. In: Ceulemans, R.J.M., Veroustraete, F., Gond, V., Van Rensbergen, J.B.H.F. (Eds.), Forest Ecosystem Modelling, Upscaling and Remote Sensing. SPB Academic Publishing, The Hague, The Netherlands, 2000, pp. 61-67.

Jaeger, L., Kessler, A., 1997. Twenty years of heat and water balance climatology at the Hartheim pine forest, Germany. Agric. For. Meteorol. 84, 25-36.

Mahrt, L., 1998. Flux sampling errors for aircraft and towers. J. Atmos. Oceanic Technol. 15, 416-429.

Monteith, J.L., 1965. Evaporation and the environment. Symp. Soc. Expl. Biol. 19, 205-234.

Running, S.W., Baldocchi, D.D., Turner, D., Gower, S.T., Bakwin, P., Hibbard, K., 1999. A global terrestrial monitoring network, scaling tower fluxes with ecosystem modeling and EOS satellite data. Remote Sensing Environ. 70, 108-127.

Twine, T.E., Kustas, W.P., Norman, J.M., Cook, D.R., Houser, P.R., Meyers, T.P., Prueger, J.H., Starks, P.J., Wesely, M.L., 2000. Correcting eddy-covariance flux underestimates over a grassland. Agric. For. Meteorol. 103, 279-300. 